\title{
磁性流体と円環状磁石によって形成されたホールの交流磁場応答 Alternating Magnetic Field Response of Hole Formed with Magnetic Fluid and Ring Permanent magnet
}

\author{
学 篠㟝 成大(秋田県大) \\ 正 須藤 誠一（秋田県大） \\ 正 高奈 秀匡（東北大） \\ 正 西山 秀哉 (東北大)
}

Michihiro SHINOZAKI, Akita Prefectural University, Ebinokuchi 84-4, Yurihonjo, Akita Prefecture 015-0055, Japan Seiichi SUDO, Akita Prefectural University

Hidemasa TAKANA, Tohoku University

Hideya NISHIYAMA, Tohoku University

Key Words: Magnetic Fluid, Permanent Magnet, Micro Actuator, Magnetic Fluid Iris, Frequency Response

\section{1. 緒 言}

磁性流体は，マグネタイト，鉄，コバルトニニッルな どの強磁性体の微粒子を水，炭化水素，ジェステルなどの 溶媒中に高密度に分散させたコロイド溶液であり，磁性と 流動性を合わせ持つ人工流体である(1). 磁性流体は, ナノ・ サイズ粒子の特性を利用したハイパーサーミアなどの医 療応用 ${ }^{(2)}$, MEMS 技術・微細加工技術などと融合すること によって磁性流体マイクロデバイスの開発 ${ }^{(3)}$ が進められて いる．著者等もこれまで，小さな円柱状永久磁石と磁性流 体を利用した往復駆動型および回転駆動型の磁性流体マ イクロデバイス ${ }^{(4)}$ ，球状永久磁石と磁性流体を利用した振 り子型のマイクロアクチュエータ(5), 磁性流体，双翅目昆 虫の翅，円柱状磁石，およびユイルを利用したマイクロエ ネルギ変換器 ${ }^{(6)}$ ，小さな円環状永久磁石とコイルを利用し た磁性流体微小液滴生成器 (7), 小さな円環状永久磁石と磁 性流体を利用した界面振動生成器 ${ }^{(8)}$ などを提案してきた。

本報では，人間の眼球の網膜に入る光の量を調節して瞳 孔を大きくしたり小さくしたりする虹彩に倣う人工機器 の開発を目指し，その基礎研究として，小さな円環状磁石 に磁性流体を吸着させ，中心部に形成されるホールの拡 大・縮小を外部磁場によって制御可能とするシステムの外 部磁場周波数応答特性を調べたものである.

\section{2. 実験装置および方法}

人間の眼は光の強弱および波長を受容する感覚器官で ある. 球状となっている眼球の角膜と水晶体(レンズ)の間 には収縮性の隔壁構造の虹彩がある．虹彩はその中央に開 孔する瞳孔を通り外から入射する光の強弱に応じて反射 的に瞳孔を縮小・拡大する機能が備わっている，本報は， このような虹彩の機能に倣うデバイスを開発するための 基礎研究である，そのため，小さな円環状磁石に磁性流体 を吸着し，小さなホールを形成する素子系を構築し，外部 から磁場によって非接触でホールの縮小・拡大を行うシス テムの特性を調べる. 図 1(a)に正面から見た虹彩の単純な 図を示し，図 1(b)に円環状磁石と磁性流体でホールを形成 した素子系を示す，磁石の極性は表裏に存在し，磁性流体 を吸着させると表裏に吸引され，ホールが形成される。

実験は，この図1(b)に示した素子系をへルムホルツコイ ルに，コイルの中心軸方向に円環状磁石のホールが並行に なるように配置し，素子系に交流磁場を印加することによ って行った. 入力信号はマルチファンクションシンセサイ ザーによって生成し，バイポーラ電源で増幅してへルムホ ルツコイルに電圧を印加した。実験では印加電圧を一定と して周波数を変化させることによって素子系の応答特性

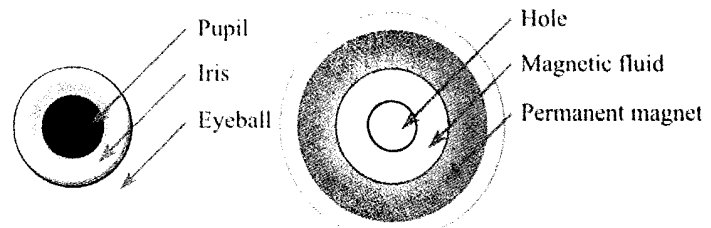

(a)Frontal view of iris (b)Frontal view of magnetic fluid hole Fig.1 Sketches of iris and magnetic fluid hole

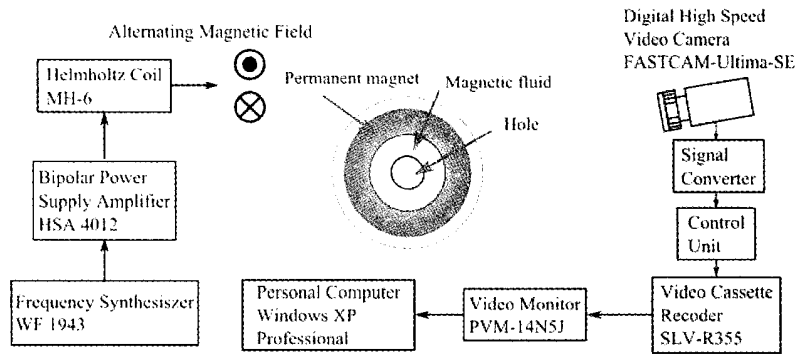

Fig.2 A schematic diagram of experimental apparatus

を調べた．素子系の忘答特性は高速度ビデオカメラシステ ムによって撮影録画し，その録画像を PC 上で解析した. 磁石と磁性流体によって形成されたホールの交流磁場に 対する応答特性を調べるための実験装置の概略図を図 2 に 示す．実験に用いた永久磁石は外径 $10 \mathrm{~mm}$, 内径 $6 \mathrm{~mm}$, 厚 さ $1 \mathrm{~mm}$, 表面磁束密度 $190 \mathrm{mT}$ の $\mathrm{Nd}_{2} \mathrm{Fe}_{14} \mathrm{~B}$ 磁石である。ま た，試料磁性流体はケロシンベース磁性流体フェリコロイ ドHC-50 である，実験は室内常温下で行い，磁性流体の温 度による磁気特性の変化は無視できる範囲にある。

\section{3. 磁性流体ホールの縮小・拡大の原理}

小さな円環状永久磁石に磁性流体を近付けると，磁気体 積力 $F_{m}$ によって吸引され図 3(b)のような磁石-磁性流体素 子系が形成される。

$$
F_{m}=-V_{l} \mu_{0} M \nabla H_{m}
$$

ここで， $V_{l}$ は磁性流体の体積， $\mu_{0}$ は真空の透磁率， $M$ は磁 化の強さ, $H_{m}$ は磁石の磁場の強さである. 円環状磁石の内 半径を $R_{1}$ (直径 $D_{1}$ ), 外半径を $R_{2}$ (直径 $D_{2}$ ), 厚さを $h$ とする とその体積 $V_{m}$ は,

$$
V_{m}=\pi h\left(R_{2}^{2}-R_{\mathrm{I}}^{2}\right)=\frac{1}{4} \pi h\left(D_{2}^{2}-D_{1}^{2}\right)
$$

となる。磁石の体積に対して，磁性流体が適量である場合， ホールが形成され，多過ぎるとホールが形成されない。

磁性流体ホールに対して，外部から円環状磁石の磁極方 向及び反対方向に磁場を印加すると磁石と干涉して，磁場 の増減が発生する. 外部磁場はヘルムホルツコイルに式(3) 


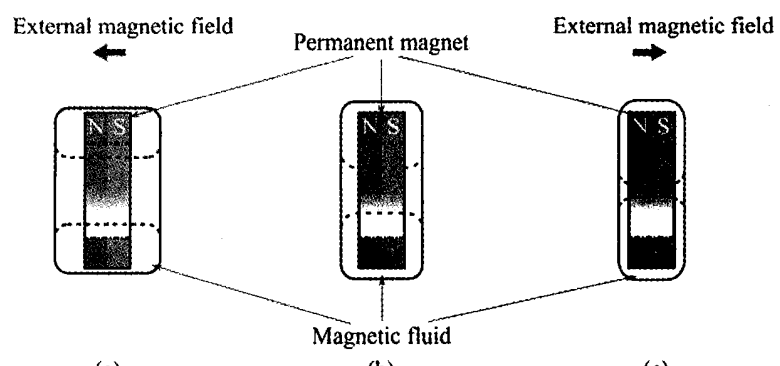

(a)

(b)

(c)

Fig.3 Magnetic fluid motions by AC magnetic field

のような交流電圧 $E$ を印加することによって生成した。

$$
E=\frac{E_{0}}{2} \sin \left(2 \pi f_{0} t\right)
$$

ここで, $E_{0} / 2$ は交流電圧の振幅, $f_{0}$ は周波数, $t$ は時間である したがって, ヘルムホルツコイルに式(3)の電圧を, 周波数 が数百 $\mathrm{Hz}$ 程度以下で印加した場合には式(4)のような交流 磁場 $H_{a}$ が生成される.

$$
H_{a}=H_{0} \sin \left(2 \pi f_{0} t-\frac{\pi}{2}\right)
$$

ここで， $H_{0}$ は交流磁場強さの振幅である．実験において $H_{0}$ は $H_{m}>H_{0}$ であり, 最大でも $H_{0}$ は $H_{m}$ の数十分の 1 以下 である. 式(4)の磁場が永久磁石と並行に作用すると，式(1) の $F_{m}$ が増大し磁性流体は永久磁石の磁極方向に流動する. その結果, 図 3(a)の状態が形成され, 磁性流体ホールは拡 大寸る. 外部磁場が永久磁石の磁場と反対方向に作用する と, 見掛けの磁場が減少し, 磁性流体はホールに向かって 流動する，結果として，図 3(c)の状態が形成される.すな わち, 外部磁場を操作することによって, 非接触でホール の拡大・縮小を制御できる.

\section{4. 実験結果および考察}

4.1 磁性流体ホールの交流磁場応答 円環状永久磁 石に磁性流体を吸着して形成した磁性流体ホールに外部 から交流磁場を印加し，ホールの応答挙動を調べた．基本 的なホールの応答は駆動原理の通りに応答し, 外部磁場の 印加に従ってホール直径の縮小・拡大の運動が観察された。 結果の一例を連続写真によって図 4 に示す. また，その時 のホール直径 $D_{h}$ の時間変化を図 5 に示す. 図 5 から磁性 流体ホールは規則的に縮小・拡大を示し，その振動数は外 部交流磁場の周波数に一致する調和振動であることがわ かる. すなわち, このホール直径 $D_{h}$ の変化は式(5)によっ て記述できる.

$$
D_{h}=D_{0}+D_{a} \sin \left(2 \pi f_{0} t-\frac{\pi}{2}-\phi\right)
$$

ここで, $D_{0}$ は交流磁場の作用の無い時のホール直径, $D_{a}$ は振動振幅， фは位相である。このような磁性流体ホール 振動はほぼすべての実験条件において観察された。

4.2 磁性流体ホール応答の周波数特性 磁性流体木 一ルは外部磁場の印加によって縮小・拡大の振動を示す. そのため, 外部磁場の周波数を変えて特性を調べた. 図 6 はその結果の一例を示している. 図 6 の縦軸は磁性流体木 一ルの無次元振動全振幅であり, 式(6)によって定義した.

$$
\bar{D}=\frac{D_{h \max }-D_{h \min }}{D_{0}}
$$

ここで, $D_{h \max }$ はホール直径の最大值, $D_{h \min }$ はホール直径 の最小值である. $\bar{D}$ は印加周波数によって変化し, 特に比 較的高い周波数において $\bar{D}$ の值は小さい.これは, へルム ホルツコイルへの印加電圧を一定として実験を行ったた

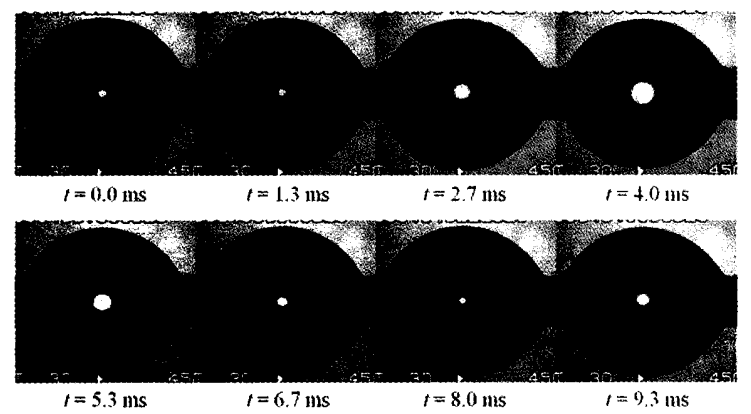

Fig.4 Selected frames of hole response

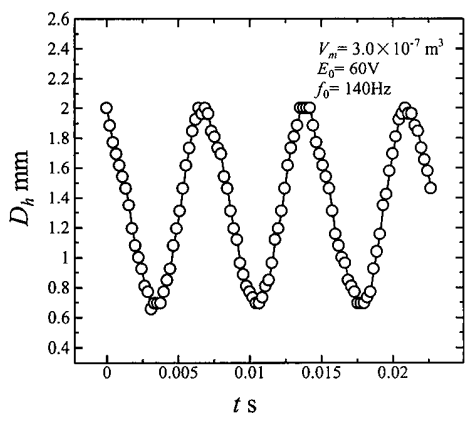

Fig.5 Diameter oscillation of magnetic fluid hole

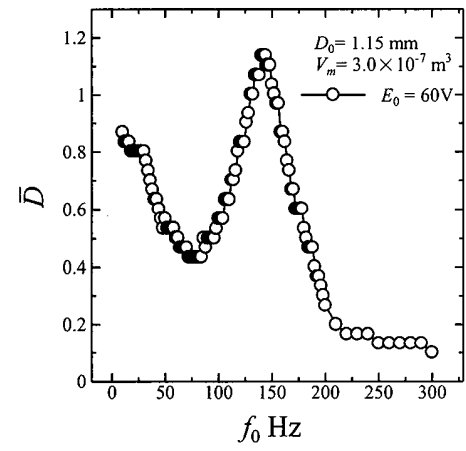

Fig.6 Frequency characteristics of hole response

めに, 周波数の増加に伴ってコイルの電流值が低下し, 外 部磁場が小さくなるためである.すなわち，コイルに電圧 $E_{0}$ を印加した場合の電流 $I$ は式(7)によって記述される.

$$
I=\frac{E_{0}}{j\left(2 \pi f_{0}\right) L}
$$

ここでLはコイルのインダクタンス, $j$ は虚数である.

4.3 印加電圧の効果 外部交流磁場の周波数を一定 として印加電圧を変えて, 磁性流体ホール応答特性を調べ た. その結果, ホール直径振動の振幅は印加電圧の増加に 伴って増大することが明らかとなった。

\section{5. 結 言}

瞳孔に倣うシステムとして, 小さな円環状永久磁石に磁 性流体を吸着させた磁性流体ホールを形成し, 外部交流磁 場によるホールの磁場応答特性を調べた.

\section{文 献}

(1) Rosensweig, R.E., Ferrohydrodynamics, Cambridge Univ. Press, (1985), 1.

(2) Laurent, S., et al., Adv. Colloid Int. Sci., 166(2011), 8.

(3) Zahn, M., J.Nanoparticle Res., 3(2001), 73.

(4) Sudo, S., et al., JSME Int. J., 48(2005), 464.

(5) Sudo, S., et al., Int. J. Appl. Electromagn. Mech., 25(2007), 95.

(6) Sudo, S., et al., J. Phys. : Cond. Mater., 20(2008), 2041.

(7) Sudo, S., et al., Int. J. Appl. Electromagn. Mech., 33(2010), 63.

(8) Sudo, S., et al., J. Magn. Magn. Mater., 323(2011),1314. 